\title{
Dynamics of Lady's slipper orchid (Cypripedium calceolus L.) population at Lake Kwiecko (West Pomerania)
}

\author{
Maciej Korczyński* \& Ewa Krasicka-Korczyńska
}

Department of Botany and Ecology, Faculty of Agriculture, University of Science and Technology in Bydgoszcz

* corresponding author (e-mail: malerudy@wp.pl)

\begin{abstract}
Cypripedium calceolus is considered an endangered species in the territory of Poland. Population of this rare species, situated at Lake Kwiecko (Western Pomerania), was regularly monitored in the years 1986-2013. The studied population has been under the permanent influence of the nearby hydroelectric power plant for almost 45 years. The field observations showed that the power plant had no negative impact on the condition of Cypripedium calceolus population. An indication of its good condition was, among others, an increase in the size - from 150 to 350 specimens within the study period.
\end{abstract}

Key words: Cypripedium calceolus, population developing, red list, long term observations

\section{Introduction}

Cypripedium calceolus L. is the largest and most ornamental representative of Orchidaceae in Poland. It is threatened due to the specific nature of its life cycle, characteristic for the whole family, and very attractive flowers that are likely to be collected for both commercial and personal purposes. For a long time, the decline in the number of its localities has been observed (Żukowski 1976; Szczęśniak et al. 2012). It does not always mean their irrevocable loss, since the reappearance of lady's slipper orchid can be sometimes observed, even after many-years absence (Gorczyca 2007). Due to high ornamental qualities of this plant, the development of successful techniques of its cultivation may be very useful (Obdržálek 2009). On one hand, this can popularize this species as a garden plant and, on the other, enable reintroduction to its primary habitats (Ramsey \& Stewart 1998; Rasmussen \& Pedersen 2011).

In Poland, C. calceolus is strictly protected by law (Regulation 2014); it is found on the List of Plants of Community Interest (Regulation 2010). In natural and seminatural populations, the abundance of $C$. calceolus can change in a very wide range. Those changes affect single shoots rather than their clusters (Kucharczyk 2010). The population of C. calceolus in the vicinity of Lake Kwiecko (Polanów District) was described by Holtzfus in 1927 (Śpiewakowski et al. 1988). In this region, localities of many other rare and protected plants were found (Śpiewakowski et al. 1987). The topographic map dating back to 1935 (Meßtischblatt 1935) show that the studied C. calceolus population was situated about $200 \mathrm{~m}$ away from the banks of the Radwia River, which has its source in Lake Kwiecko. The place was forested and referred to as "Protection area" (ger. 'Naturschutz'). In the vicinity there are visible traces of the castle-town dating back to the early Middle Ages (Skrzypek 2010). Thus, it can be assumed that the area of today's occurrence of lady's slipper orchid used to be intensively penetrated by people. Today, this site is neither protected nor recognized as cultural and natural heritage.

After putting into operation the pumped-storage hydro-electric power plant in Żydowo in 1971, the local population of $C$. calceolus has been exposed to its direct impact. The water level in Lake Kwiecko can increase by $3.1 \mathrm{~m}$ a day, which has led to the formation of the floodplain zone covering the area of 54 ha. The increase 
in the primary area of the lake affects the ground water dynamics of the adjacent areas (Śpiewakowski 1974). At present the population of lady's slipper orchid is situated about $1 \mathrm{~m}$ above the maximum level of the floodplain zone and about $20 \mathrm{~m}$ away from its border.

The materials published earlier show that the population of lady's slipper orchid was developing under the wet-ground forest stand cover. It covered the patch of about $1000 \mathrm{~m}^{2}$. Over 1986-1989 there were recorded from 282 to 324 shoots of that species, including up to $12.3 \%$ flowering shoots (Śpiewakowski et al. 1988, 1990; Korczyński \& Śpiewakowski 1991).

The aim of this paper is to evaluate the dynamics and conditions of Cypripedium calceolus population developing in the neighbourhood of the water reservoir affected by a pumped-storage hydro-electric power station over the last 28 years.

\section{Material and methods}

Observations of Cypripedium calceolus population of at Lake Kwiecko were made in 1990, 1991, 2006 and 2008. Up to 2008, these observations were carried out during the phase of full plant flowering and in 2013, they were performed during the fruit-setting phase. The height of all vegetative shoots to the base of the highest leaf and the height of generative shoots to the base of the ovary have been measured. The juvenile individuals were considered those which height did not exceed $2 \mathrm{~cm}$. The shoots were plotted applying the orthogonal survey method, which was used to prepare a choropleth map showing distribution of individuals (each shoot was treated as a single individual). The structure of their spatial distribution was determined according to Kershaw (1978) on a permanent plot $32 \times 32 \mathrm{~m}$ in size. For comparative purposes, unpublished data from the years 1987-1989 were used to prepare a choropleth map and evaluate the plant height in respective years.

The significance of differences in the height of individuals was verified with a single-factor analysis of variance and the hypothesis on the lack of differences in their height structure - with the Kolmogorov-Smirnov test (Łomnicki 1999).

Applying the methodology of evaluation the state of population and habitats (Kucharczyk 2010), changes in the condition of lady's slipper orchid and the state of its occurrence in the locality at the Lake Kwiecko in 1986-2013 were determined.

\section{Results}

During five observation seasons, it was found that the number of individuals of lady slipper's orchid ranged from 150 in 1991 to 358 in 2013. The share of flowering individuals did not exceed $9 \%$ (Table 1). The flowering shoots of Cypripedium calceolus are strongly sensitive to damage. In 1990 and 1991, no plants in the generative phase were found. However, there were noted 58 and 4 damaged specimens, respectively. They could have included individuals at the flowering stage. The damage could result from, e.g., close vicinity of a busy, at that time, forest road running along the southern border of the population. The number of flowering shoots identified over 1990-2013 ranged from $1.1 \%$ to $6.7 \%$. They attained maximum height in $2006-36.2 \mathrm{~cm}$; the same year, their share in the population was greatest and it accounted for $8.9 \%$. In 2013, out of 24 blooming stems 8 fruits were set.

In the period studied, the mean vegetative shoot heights ranged from 6.5 to $9.8 \mathrm{~cm}$. The highest value was noted in 2013, when the highest number of individuals of lady slipper's orchid was recorded. Relatively

Table 1. Properties of the studied Cypripedium calceolus population

\begin{tabular}{|c|c|c|c|c|c|c|c|c|c|}
\hline \multirow{2}{*}{ Year } & \multirow{2}{*}{$\begin{array}{c}\text { Total } \\
\text { number } \\
\text { of shoots }\end{array}$} & \multirow{2}{*}{$\begin{array}{l}\text { Percentage } \\
\text { of flowering } \\
\text { shoots }(\%)\end{array}$} & \multirow{2}{*}{$\begin{array}{c}\text { Percentage } \\
\text { of juvenile } \\
\text { shoots } \\
(\%)\end{array}$} & \multicolumn{2}{|c|}{$\begin{array}{l}\text { Height of flowering } \\
\text { shoots }\end{array}$} & \multirow{2}{*}{$\begin{array}{c}\text { Vegetative } \\
\text { shoots CV\% }\end{array}$} & \multirow{2}{*}{$\begin{array}{c}\text { Number of } \\
\text { destroyed } \\
\text { shoots }\end{array}$} & \multirow{2}{*}{$\begin{array}{l}\text { Number of } \\
\text { clumps }\end{array}$} & \multirow{2}{*}{$\begin{array}{l}\text { Average } \\
\text { number of } \\
\text { shoots per } \\
\text { clump }\end{array}$} \\
\hline & & & & $(\mathrm{cm})$ & CV\% & & & & \\
\hline 1986 & $290^{*}$ & $8.6^{*}$ & - & $34.2 * *$ & 13,8 & - & 0 & - & - \\
\hline 1987 & $290 *$ & $9.0 *$ & - & - & - & - & 0 & 54 & 2.3 \\
\hline 1988 & $324^{*}$ & $12.3^{*}$ & 0.0 & $34.2^{*}$ & 28,1 & 43.6 & 0 & 49 & 2.5 \\
\hline 1989 & $282^{*}$ & $8.2 *$ & 2.5 & $33.9 *$ & 18,1 & 52.3 & 0 & 50 & 2.4 \\
\hline 1990 & 184 & - & 1.6 & - & - & 53.8 & 58 & 31 & 2.5 \\
\hline 1991 & 150 & - & 0.7 & - & - & 41.4 & 4 & 17 & 2.4 \\
\hline 2006 & 190 & 8.9 & 3.2 & 35.7 & 12.9 & 62.1 & 0 & 31 & 2.2 \\
\hline 2008 & 177 & 1.1 & 6.2 & 26.5 & - & 60.6 & 0 & 30 & 1.9 \\
\hline 2013 & 358 & 6.7 & 0.6 & 30.9 & 27.1 & 44.8 & 2 & 61 & 2.7 \\
\hline
\end{tabular}

Explanations: * - Korczyński \& Śpiewakowski 1991, ** - Śpiewakowski et al. 1990 


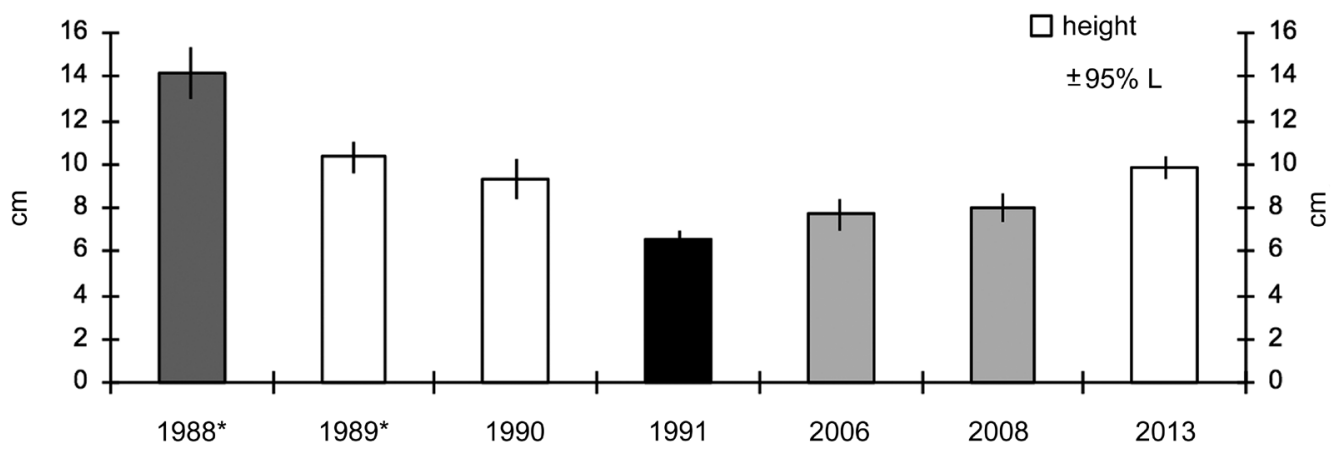

Fig. 1. The mean height of the Cypripedium calceolus vegetative shoots and their $95 \%$ boundaries of confidence. Similar measurements were marked in the same pattern

Explanation: * - Korczyński \& Śpiewakowski 1991

lowest differences in the spectrum of population height were found for individuals reaching from 8 to $12 \mathrm{~cm}$. The calculated value of $F=33.4$ points that at $p<0.01$ one can reject the zero hypothesis assuming a lack of differences in the height of vegetative individuals over $1988-2013$ in the period studied. The non-compliance of $95 \%$ confidence boundaries of the means points to the separation of the shoot height in 1991, when the plants were lowest. They were significantly highest in 1988. Measurements of the height of vegetative shoots carried out in 1989, 1990 and 2013 and, then, in 2006 and 2008 form separate groups which clearly differ one from another (Fig. 1), however, found in the middle of the range of variation identified. Although the data in 2013 were collected a few weeks later than in the previous periods, they do not stand out from their entire set.

The share of plants in the ranges every $4 \mathrm{~cm}$, as compared to the mean for all research periods, did not change significantly. The Kołmogorov-Smirnov test value ranged from 0.08 to 0.14 and did not exceed the critical value of $1.34(p=0.05)$. One cannot thus state that the mean height reflects the share of shoots from a specific range of that variation.
Over 1990-2013, the greatest share of the smallest plants (up to $2 \mathrm{~cm} \mathrm{high),} \mathrm{interpreted} \mathrm{as} \mathrm{juveniles,} \mathrm{was}$ noted in $2008-6.4 \%$. In 1988, they were not reported at all (Table 1). In consequence, the patches of $C$. calceolus at Kwiecko Lake can be characterised as diversified in the course of years, still, containing the low ratio of juvenile shoots. The ratio of juvenile shoots over past years has not even reached the half of the value given by Nicolè et al. (2005).

In the population under study, the C. calceolus individuals occurred in a form of small clusters - clumps and as single shoots. Throughout the observation period, 2 to 3 shoots were most frequently noted in the clump, so they were not clearly separated physiognomically. The number of clumps ranged from 17 in 1991 to 58 in 2013 (Table 1). The coefficients of variation in the number of clumps and the total number of shoots were similar. They were $37.5 \%$ and $32.0 \%$, respectively. The clusters of higher orders covered the areas of about 4 to about $128 \mathrm{~m}^{2}$ and they could have been related to the variation in microhabitats at the locality (Fig. 3).

The area covered by the population of Lady's slipper orchid in the years 1987-2006 was relatively stable. Slight changes in the shape of the patch did not affect the

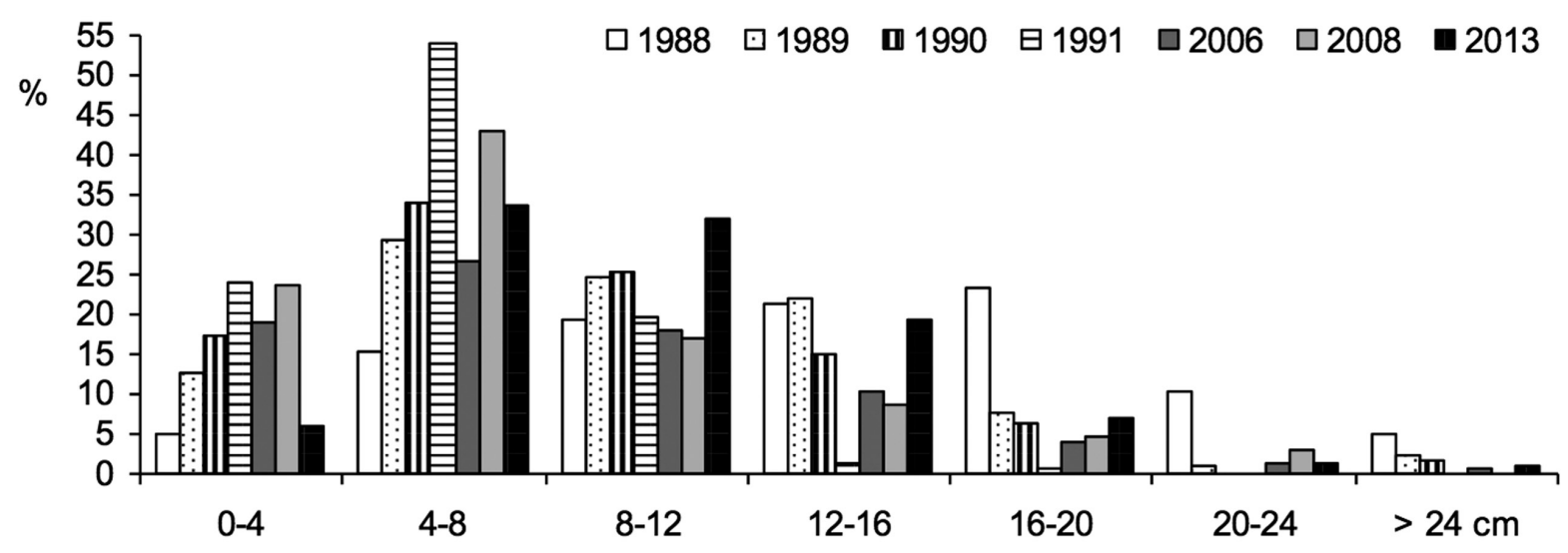

Fig. 2. The height structure of Cypripedium calceolus individuals in 1988-2013 


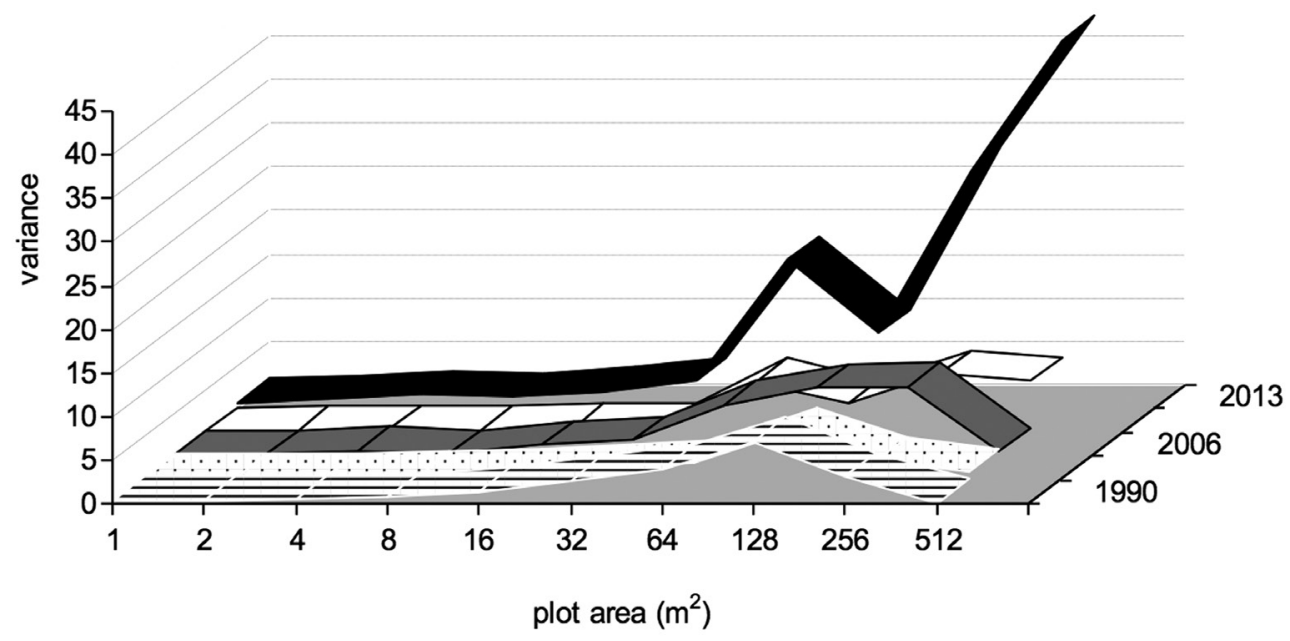

Fig. 3. Distribution pattern of the Cypripedium calceolus shoots in 1990-2013

overall surface occupuied by the population, which over that period ranged from 500 to $600 \mathrm{~m}^{2}$. Only in 2008 and 2013, the presence of Cypripedium shoots close to the border of the forest, north from the original patch, has been observed (Fig. 4).

The evaluation of the habitat of the population, in compliance with the methodology assumed in its monitoring, demonstrated, in general, its stability (Table 2). The parameters evaluated as adverse were shading and habitat overgrowing. The neighbourhood of the water power plant has been supposed to have an effect on the habitat, however, it was considered inconsiderable. The traces of shoot damage were identified to show a high effect on the population. The other indicators of the habitat condition were considered appropriate. The evaluation of the population in terms of the number of shoots and clumps showed changes in the whole range of the indicator values. Throughout the observation period, the share of flowering shoots was too low compared with vegetative shoots.

Table 2. Cypripedium calceolus indicators of habitat and population conditions at Lake Kwiecko

\begin{tabular}{|c|c|c|c|c|c|c|c|c|c|}
\hline Indicator & 1986 & 1987 & 1988 & 1989 & 1990 & 1991 & 2006 & 2008 & 2013 \\
\hline Pollination efficiency & $\mathrm{xxx}$ & $\mathrm{xxx}$ & $\mathrm{xxx}$ & $\mathrm{xxx}$ & $\mathrm{xxx}$ & $\mathrm{xxx}$ & $\mathrm{xxx}$ & $\mathrm{xxx}$ & U2 \\
\hline Habitat fragmentation & FV & FV & FV & FV & FV & FV & FV & FV & $\mathrm{FV}$ \\
\hline Expansive species & $\mathrm{FV}$ & FV & FV & FV & FV & $\mathrm{FV}$ & FV & FV & FV \\
\hline Adventive invasive species & $\mathrm{FV}$ & FV & FV & FV & FV & FV & FV & FV & $\mathrm{FV}$ \\
\hline Number $(\%)$ of generative individuals & $\mathrm{U} 2$ & $\mathrm{U} 2$ & $\mathrm{U} 2$ & $\mathrm{U} 2$ & $\mathrm{xxx}$ & $\mathrm{xxx}$ & $\mathrm{U} 2$ & $\mathrm{U} 2$ & $\mathrm{U} 2$ \\
\hline Number of clumps & $\mathrm{xxx}$ & $\mathrm{xxx}$ & U1 & FV & $\mathrm{U} 2$ & $\mathrm{U} 2$ & FV & FV & $\mathrm{FV}$ \\
\hline Number of individuals & $\mathrm{xxx}$ & FV & FV & $\mathrm{U} 2$ & $\mathrm{U} 2$ & $\mathrm{U} 2$ & FV & U1 & FV \\
\hline Number of vegetative individuals & $\mathrm{xxx}$ & $\mathrm{U} 2$ & $\mathrm{U} 2$ & U2 & $\mathrm{U} 2$ & $\mathrm{U} 2$ & $\mathrm{U} 2$ & $\mathrm{U} 2$ & $\mathrm{U} 2$ \\
\hline Number of shoots & $\mathrm{xxx}$ & FV & FV & $\mathrm{U} 2$ & $\mathrm{U} 2$ & $\mathrm{U} 2$ & FV & U1 & FV \\
\hline Dead organic material & FV & FV & FV & FV & FV & FV & $\mathrm{FV}$ & FV & FV \\
\hline Space for germination & FV & $\mathrm{FV}$ & FV & FV & FV & FV & FV & FV & FV \\
\hline Negative effect from the surroundings & U1 & U1 & U1 & U1 & $\mathrm{U} 2$ & $\mathrm{U} 2$ & U1 & U1 & $\mathrm{FV}$ \\
\hline Presence of seedlings & $\mathrm{xxx}$ & $\mathrm{xxx}$ & $\mathrm{U} 2$ & U1 & $\mathrm{U} 2$ & $\mathrm{U} 2$ & U1 & U1 & $\mathrm{U} 2$ \\
\hline Shading & $\mathrm{U} 2$ & $\mathrm{U} 2$ & $\mathrm{U} 2$ & $\mathrm{U} 2$ & $\mathrm{U} 2$ & $\mathrm{U} 2$ & $\mathrm{U} 2$ & $\mathrm{U} 2$ & $\mathrm{U} 2$ \\
\hline Area of potential habitat & $\mathrm{FV}$ & FV & FV & FV & FV & $\mathrm{FV}$ & FV & FV & $\mathrm{FV}$ \\
\hline Area of occupied habitat & $\mathrm{FV}$ & FV & FV & FV & FV & FV & FV & FV & FV \\
\hline Health status & FV & FV & FV & FV & U1 & U1 & FV & FV & FV \\
\hline Habitat overgrowing coefficient & $\mathrm{U} 2$ & $\mathrm{U} 2$ & $\mathrm{U} 2$ & $\mathrm{U} 2$ & $\mathrm{U} 2$ & $\mathrm{U} 2$ & $\mathrm{U} 2$ & $\mathrm{U} 2$ & $\mathrm{U} 2$ \\
\hline Distribution type & U1 & U1 & U1 & U1 & U1 & U1 & U1 & U1 & U1 \\
\hline Undergrowth height & FV & FV & FV & FV & FV & FV & FV & FV & FV \\
\hline
\end{tabular}

Explanations: FV - appropriate, U1 - unsatisfactory, U2 - bad, xxx - unknown 

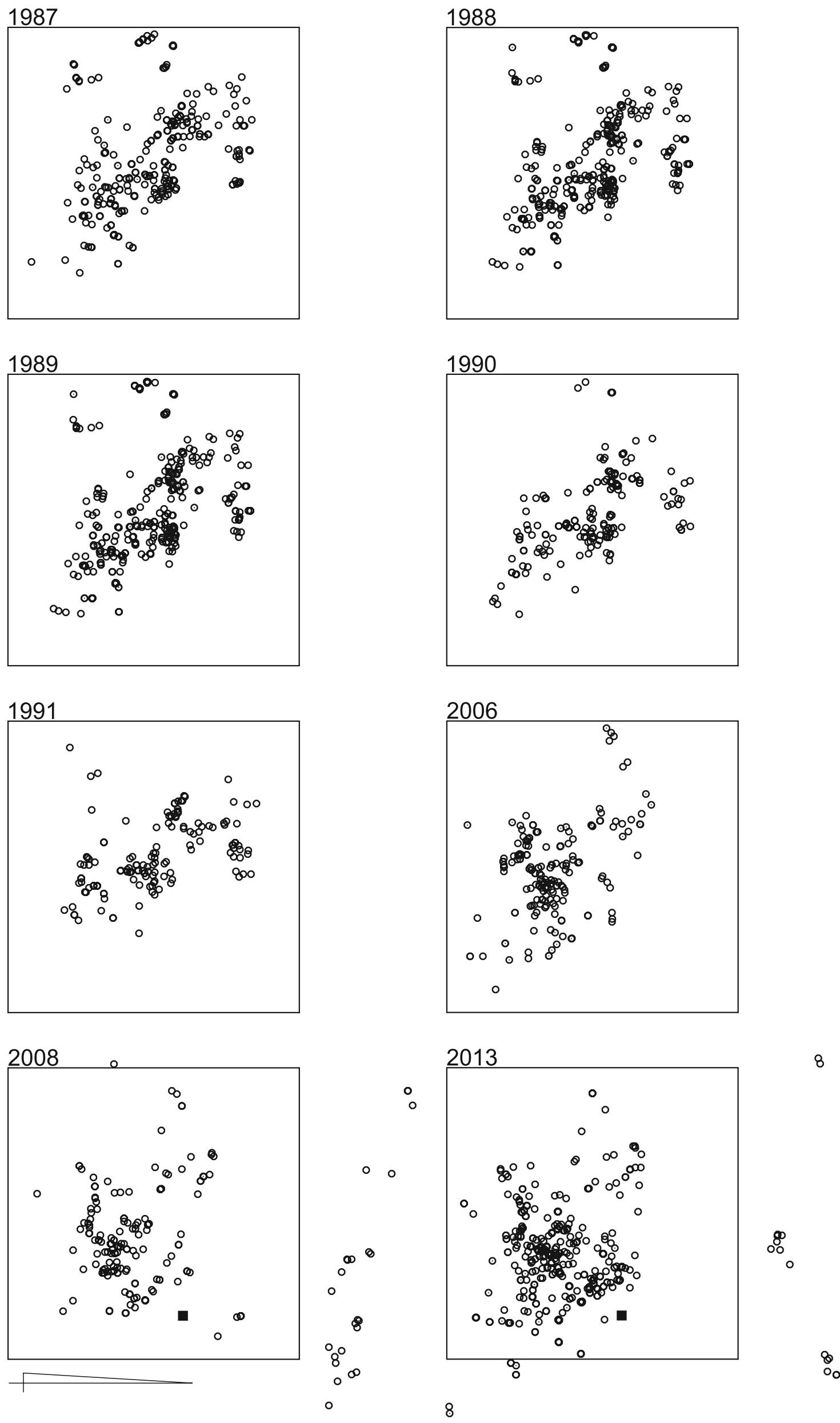

Fig. 4. Choropleth maps of the Cypripedium calceolus shoot distribution (borders of the permanent plot $32 \times 32 \mathrm{~m}$ have been marked) 


\section{Discussion}

The population of Cypripedium calceolus at the Lake Kwiecko undergoes fluctuations in the number and size of individuals. In the years, 1986-1989 about 300 of them were recorded (Korczyński \& Śpiewakowski 1991). Between the years 1990 and 2008, the population size decreased and fell within the range of 150-190 to reach the highest noted number in 2013. This variation is not as high as in other localities (Michalik \& Michalik 2000). It may happen that shoots of lady's slipper orchid in a given locality are not noted for a few years. In the Segiet nature reserve in Bytom, the specimens of C. calceolus were reported after a more than 25-years break (Gorczyca 2007). The characteristic feature of the species representing the lady's slipper orchid genus is the occurrence of a few-year dormancy periods (Shefferson 2006). Thus, even a considerable decrease in the number of individuals does not have to point to significant threats to the survival of population.

The height structure of vegetative shoots in 19861989 and 1990-2013 was similar, which may lead to an assumption that it was corresponding to the structure of developmental stages of the population. The share of flowering shoots over the last period was, however, lower than in the previous one. Throughout the period of observation the population at Lake Kwiecko showed a few-fold lower share of generative shoots compared with populations in the Biebrza River Valley (Arciszewska 2003). However, it should be stressed that in the Biebrza National Park in populations with a high share of flowering shoots, their percentage ranges from 6.2 to $62 \%$, while in smaller populations, flowers are often missing (Brzosko \& Ostrowiecka 2013). Long standing observations of flowering in the Tatra National Park show that the generative individuals always account for more than $25 \%$ of the population (Delimat 2008). At the same time, flowering of lady's slipper orchid varies considerably in individual populations, however, it does not affect the prospect of their survival.

The height of generative specimens corresponded with the height found in other regions (Brzosko \& Werpachowski 1991; Kull 1999; Arciszewska 2003; Krasicka-Korczyńska et al. 2008). This indicates that the plant in the reproductive phase, irrespective of circumstances, fully uses its biological potential. In the vegetative phase, individuals in the population at Lake Kwiecko were definitely lower than in other regions. They reached mostly up to $2 / 3$ of the height noted by above mentioned authors. Individuals defined as adults by Nicolè et al. (2005) were not observed. The ratio of juvenile shoots over past years has not even reached the half of the value given by Nicolè et al. (2005). This can result from difficult light conditions in the studied locality.
The effectiveness of pollination in 2013 was $1 / 3$ lower than reported in the study conducted on 3500 flowers in Estonia (Kull 1998). However, it fells within the range reported by Przydyba (2001) for populations from the Biebrza River Valley. In the Biebrza populations, a share of fruit-bearing shoots reaches $25 \%$, which can be periodically connected with the activity of pollinating insects, especially that no autogamy was observed in lady slipper's orchid (Brzosko \& Werpachowski 1991; Przydyba 2001). In the neighbourhood of the investigated locality, the only open area is a floodplain, affected by the nearby pumped-storage hydro-electric power plant. Thus, a low number of generative shoots and relatively low proportion of fruit bearing shootsmay result from the lack of suitable habitats for pollinators. Insects pollinating lady's slipper orchid find optimal conditions in forest ecotones with sunny spots (Antonelli et al. 2009), which are missing in this region.

The populations of the Biebrza River Valley or the Tatra National Park develop in the patches with varied light conditions. As pointed by Kucharczyk (2010), one of threats posed to populations of Cypripedium is excessive shading. The population at the Lake Kwiecko differs from others in terms of its development under the complete cover of deciduous tree stand (Śpiewakowski et al. 1990). It grows in the conditions of constant and considerable shading. In the population in Żydowo, this a factor that limits the development of generative shoots.

Previous studies showed that the patch kept its shape (Korczyński \& Śpiewakowski 1991). Since 2008, the increase in the patch size was observed. The individuals of lady's slipper orchid started to occupy the earlier unoccupied part of the available habitat located closer to the lake shore. Also, at that period, a definitely greater cover by vegetation of the floodplain zone of the lake was observed than in the years 1985-1989, which can be connected with less intensive fluctuations of the water level in the lake caused by the operation of the power plant.

The spatial structure of the shoot clusters corresponded to the structure observed earlier (Śpiewakowski et al. 1990; Korczyński \& Śpiewakowski 1991). It reflects a poor habitat variation within the patch. Clumps within the patch had half of shoots reported by Brzosko \& Werpachowski (1991), as it seems, for clumps presumably developing in better light conditions in the patches of the Biebrza River Valley. The long standing variation in the number of clumps and the total number of shoots developing at the Lake Kwiecko under the cover of the forest were comparable. In other habitat conditions, lower fluctuations were recorded for the number of clumps than for the number of single shoots (Kucharczyk 2010). 
C. calceolus has been observed in the examined locality for about 100 years. This period is determined by Nicolè et al. (2005) as average longevity for the individuals of this species, but others claim it can reach over 300 years. During 28 years of research, a large fluctuation in the total number of shoots, but, more or less, constant size and spatial distribution of the population were observed. Persistence of the Lady's slipper orchid at Kwiecko Lake results from its strong genetical diversification characteristic for Pomeranian populations. High efficiency in vegetative propagation along with relatively small number of sexually reproducing individuals is of considerable significance. In these circumstances, the environmental pressure can lead to the decrease in genetic within the studied patch (Brzosko et al. 2011).

When comparing the results of the observations of lady's slipper orchid in the locality at the Kwiecko Lake with the results of the national survey of 2008 , it is remarkable that the development of most of populations is similarly limited by an impact of shade (Monitoring 2014). As compared with the national results, a very low share of flowering shoots in the patch studied was observed. In this locality, there is no competition with other herbaceous plants, unlike in many localities in the Biebrza National Park (Brzosko \& Ostrowiecka 2013). A potential for further habitat filling, both at the national level and in the studied patch at the Lake Kwiecko, is good.

\section{Conclusion}

Results of the analysis of Cypripedium calceolus population parameters observed over recent years reveal that neighbourhood of the pumped-storage hydroelectric power plant hasn't had any significant impact on this population condition. Changes in the population size across respective periods of observations can reach almost 50\% (the years 2008 and 2013), nevertheless high numbers of shoots were noted both in the 1980s and recently. Fluctuations in respective periods affect the height of vegetative shoots in a similar rhythm as the population size. The key factor affecting development of lady's slipper orchid at Lake Kwiecko is shading by higher vegetation. Although, shading is a limiting factor, it does not pose a threat to the survival of studied population.

\section{References}

Antonelli A., Dahlberg C. J., Carlgren K. H. I. \& AppelqVIST T. 2009. Pollination of the Lady's slipper orchid (Cypripedium calceolus) in Scandinavia. Nord. J. Bot. 27: 1-8.

ArciszewsKa U. 2003. Struktura ekologiczna i genetyczna wyspowych populacji obuwika pospolitego (Cypripedium calceolus) w Biebrzańskim Parku Narodowym. In: S. Maciak, Ł. Mazurek \& W. ChętNicki (eds.). Materiały VII Ogólnopolskiego Przeglądu Działalności Studenckich Kół Naukowych Przyrodników. Wyd. Uniwersytetu w Białymstoku, pp. 41-46. Białystok.

Brzosko E. \& Ostrowiecka B. 2013. Obuwik pospolity w Biebrzańskim Parku Narodowym. Institute of Biology, University of Bialystok. Manuscript.

Brzosko E. \& Werpachowski C. 1991. Cypripedium calceolus L. w kotlinie Biebrzy - analiza populacji lokalnych. Phytocoenosis 3: 253-257.

Brzosko E., Wróblewska A., Taląaj I. \& Wasilewska E. 2011. Genetic diversity of Cypripedium calceolus in Poland. Plant Syst. Evol. 295: 83-96.

Delimat A. 2008. Charakterystyka populacji obuwika pospolitego (Cypripedium calceolus L.) nad Końskim Żłobem w Tatrzańskim Parku Narodowym. In: E. Brzosko, A Wróblewska \& I. Tąąaj (eds.). Problemy badawcze i perspektywa ochrony storczykowatych w Polsce, pp. 65-68. Uniwersytet w Białymstoku, Biebrzański Park Narodowy, Osowiec-Twierdza.
GorCZYCA M. 2007. Obuwik pospolity Cypripedium calceolus L. w rezerwacie Segiet w Bytomiu. Chrońmy Przyr. Ojcz. 63(3): 42-47.

KERSHAW K. A. 1978. Ilościowa i dynamiczna ekologia roślin. 382 pp. PWN, Warszawa.

KoRCZYŃSKI M. \& ŚPIEWAKOWSKI E. R. 1991. Struktura rozmieszczenia i wielkości populacji obuwika pospolitego Cypripedium calceolus L. nad jeziorem Kwiecko (woj. koszalińskie). Prądnik. Prace Muz. Szafera 3: 183-191.

Krasicka-KorczyńsKa E., Korczý́sKi M. \& MikLaszewski R. 2008. Cypripedium calceolus L. w rezerwacie "Wyspa na jeziorze Wielkie Partęczyny”. In: E. Brzosko, A. Wróblewska \& I. Talalaj (eds.). Problemy badawcze i perspektywa ochrony storczykowatych w Polsce, pp. 69-75. Uniwersytet w Białymstoku, Biebrzański Park Narodowy, Osowiec-Twierdza.

KuCHARCZYK L. 2010. 1902 Obuwik pospolity Cypripedium calceolus L. In: J. Perzanowska (ed.). Monitoring gatunków roślin. Przewodnik metodyczny, 1: 8398. Biblioteka Monitoringu Środowiska, Inspekcja Ochrony Środowiska, Warszawa.

KuLL T. 1998. Fruit-set and recruitment in populations of Cypripedium calceolus L. in Estonia. Bot. J. Linn. Soc. 126: 27-38.

Kull T. 1999. Biological flora of the British Isles. Cypripedium calceolus L. J. Ecol. 87: 913-924. 
ŁoMnICKI A. 1999. Wprowadzenie do statystyki dla przyrodników. 262 pp. Wyd. Nauk. PWN, Warszawa.

Meßtischblatt 1935. Topographische Karte 1:25 000, Sydow.

Michalik S. \& Michalik R. 2000. Dynamika populacji i aktywna ochrona obuwika pospolitego Cypripedium calceolus L. w rezerwacie przyrody "Michałowiec". Chrońmy Przyr. Ojcz. 56(6): 13-28.

Monitoring 2014. Monitoring gatunków i siedlisk przyrodniczych ze szczególnym uwzględnieniem specjalnych obszarów ochrony siedlisk Natura 2000. Wyniki monitoringu. Cypripedium calceolus. http://www. gios.gov.pl/siedliska/default.asp?nazwa=wyniki_szcz egolowe_2006_2008_rosliny\&je=pl. Access date 05.08.2014.

Nicolè F., Brzosko E. \& Till-Bottraud I. 2005. Population viability analysis of Cypripedium calceolus in a protected area: longevity, stability and persistence. J. Ecol. 93: 716-726.

OBDRŽÁLEK J. 2009. Cultivation of Cypripedium calceolus L. ex vitro seedlings in outdoor conditions. Hort. Sci. (Prague) 36(4): 162-170.

PRZYDYBa K. 2001. Efektywność zapylania w wyspowych populacjach obuwika pospolitego (Cypripedium calceolus) oraz listery jajowatej (Listera ovata) w Dolinie Biebrzy. In: T. WiszNiEwSKa \& B. BorczyK (eds.). Materiały V Przeglądu Działalności Studenckich Kół Naukowych Przyrodników, pp. 53-58. Uniwersytet Wrocławski, Wydawnictwo TINCA sp. z o. o., Wrocław.

Ramsey M. M. \& Stewart J. 1998. Re-establishment of the lady's slipper orchid (Cypripedium calceolus L.) in Britain. Bot. J. Linn. Soc. 126: 173-181.

Rasmussen H. N. \& Pedersen H. Æ. 2011. Cypripedium calceolus germination in situ: seed longevity, and dormancy breakage by long incubation and cold winters. Eur. J. Environ. Sci. 2: 69-70.

REgulation 2010. Regulation of the Minister of Environment of 13 April 2010 on habitats and species being the subject of interest for the European Union, and the selection criteria for the areas qualifying for recogni- tion or designation as the Natura 2000 areas. Journal of Laws 2010.77.510.

Regulation 2014. Regulation of the Minister of Environment of 16 October 2014 on wild species of plants under protection. Journal of Laws 2014, item 1409.

SHEFFERSON R. P. 2006. Survival costs of adult dormancy and the confounding influence of size in lady's slipper orchids, genus Cypripedium. Oikos 115: 253-262.

SkrzyPeK I. 2010. Z pradziejów gminy Polanów. In: W. RĄCZKOWSKI \& J. SROKA (eds.). Historia i kultura Ziemi Sławieńskiej. Miasto i Gmina Polanów, 10: 39-116. Fundacja "Dziedzictwo" Sławno.

ŚPiewakowski E. 1974. Badania nad zmianami w szacie roślinnej pod wpływem nierytmicznych wahań poziomów wody w zespole jezior „Elektrowni Wodnej Żydowo". 152 pp. WSP, Słupsk.

ŚPIEWAKOWSKI E. \& KoRCZYŃSKI M. 1993. Wpływ elektrowni wodnej w Żydowie na dynamikę przemian flory jezior Kamienno i Kwiecko oraz ich stref zalewowych. Fragm. Flor. Gobot. 38(1): 303-318.

Śpiewakowski E., Korczyński M., Spanidis A. \& Piasecki J. 1990. Stanowisko Cypripedium calceolus L. nad jeziorem Kwiecko w województwie koszalińskim. Bad. Fizjogr. Pol. Zach. seria B-Botanika 40: 221-230.

Śpiewakowski E., Spanidis A., Korczyński M. \& Piasecki J. 1987. Rzadsze gatunki roślin naczyniowych przyległych do elektrowni wodnej Żydowo. Zeszyty Naukowe 141, Rolnictwo 23: 5-11.

Śpiewakowski E., Spanidis A., Piasecki J. \& Korczyński M. 1988. Największe stanowisko obuwika pospolitego Cypripedium calceolus L. na Pomorzu Zachodnim. Chrońmy Przyr. Ojcz. 44( 4): 74-78.

Szczęśniak E., Jakubska-Busse A. \& Liwiński M. 2012. Zróżnicowanie i rozmieszczenie zbiorowisk z udziałem Cypripedium calceolus L. (Orchidaceae) na Dolnym Śląsku. Acta Botanica Silesiaca 8: 97-128.

Żukowski W. 1976. Zanikanie storczyków w Polsce niżowej w świetle analizy współczesnego rozmieszczenia wybranych gatunków. Phytocoenosis 5(3-4): 215-226. 